\title{
Prevalence of Heartburn in Abidjan, a Black African Country, and Associated Factors
}

\author{
Constant Assi*, Siaka Koné, Antonin W. Ndam Ndjitoyap, Amadou Ouattara, \\ Laté Mawuli Lawson-Ananissoh, Diallo Djenabou, Stanislas Doffou, Jean-Kalpy Coulibaly, \\ Christian Ebela, Dramane Soro, Emile Allah-Kouadio, Marie-Jeanne Lohouès-Kouacou, \\ Benoît-Mathieu Camara
}

Division of Gastroenterology University Hospital of Cocody, Abidjan, Côte d'Ivoire

Email: assiconstant@yahoo.fr

Received 27 February 2014; revised 31 March 2014; accepted 8 April 2014

Copyright (C) 2014 by authors and Scientific Research Publishing Inc.

This work is licensed under the Creative Commons Attribution International License (CC BY).

http://creativecommons.org/licenses/by/4.0/

c) (i) Open Access

\begin{abstract}
Aims: To determine the prevalence and risk factors of heartburn in Abidjan, a black African city. Patients and Methods: cross-sectional study from June 15 to September 30, 2003. One thousand nine hundred forty (1940) persons from five health zones of the city Abidjan were included after their informed consent. Socio demographic and clinical parameters were collected using a questionnaire in an interview format. Heartburn was defined as a discomfort or burning sensation extending from the sternal manubrium to the base of the neck. Factors related to the complaint were asked such as predisposing factors, habits (tobacco, alcohol and coffee intake) and body mass index. Stepwise multiple logistic regression analyses were used to examine associations between these factors and heartburn. Results: Among 1940 respondents (mean age $28 \pm 9$ years; sex ratio (M:F) 0.86), heartburn occurred in 433 persons (once a week in $9.2 \%$ of case (178 persons)). Five factors were statistically associated with heartburn: male sex $(p=0.025,0 R=0.555$ [CI95\% 0.331 - 0.930]), heartburn in a family member $(p=0.010,0 R=1.765[95 \% C I 1.143-2.725])$, constipation $(\mathrm{p}=0.011, \mathrm{OR}=2.182[95 \% \mathrm{CI} 11,953,983])$, right lateral decubitus $(\mathrm{p}=0.001, \mathrm{OR}=6.247$ [95\%CI 2.079 - 18.775]) and after a meal ( $p=0.000,0 R=2.643$ [95\%CI 1.594 4.383]). Conclusion: Heartburn is common in this black African population. Male sex appears to be less associated. Constipation, right lateral decubitus and after a meal are trigger factors for heartburn. Heartburn in a family member is a risk factor.
\end{abstract}

\section{Keywords}

Gastro-Esophageal Reflux Disease; Heartburn; Regurgitation; Abidjan; Epidemiology; Clinical

*Corresponding author. 


\section{Introduction}

Heartburn is a public health problem in the West [1]. Its prevalence is high as well as its socio-economic costs [2]. It affects the quality of life of patients [3] [4] and exhibits long-term risk of esophageal adenocarcinoma via the Barrett's esophagus [5] [6].

In Africa, few studies have been published [7]-[14]. They are exclusively hospital and endoscopic series unrepresentative of the general population. Besides, few of the studies have specifically addressed heartburn in a black African context [8] [15] [16]. Mindful of the possible influence of differing demographic, nutritional, lifestyle and genetic factors, the present study was designed. The aim of our study was to determine in Abidjan, Cote d'Ivoire, prevalence and associated factors of heartburn.

\section{Materials and Methods}

\subsection{Subjects}

It was a cross-sectional study from June 15, 2003 September 30, 2003 inclusive. Abidjan is a city of 5 million people whose health division is made in five areas balanced health center. All persons over 15 years, living in one of five health zones of the city of Abidjan were included. All study participants had given their informed consent. Patients refusing or unable to respond to the questionnaire were not included in the study.

The sample size chosen was estimated at least 1825 persons in a calculated expected prevalence of $5 \%$ with a risk alpha and beta respectively $5 \%$ and $1 \%$. The construction of the sample was made taking into account the administrative division population.

First of all, the nature and objective of the questionnaire were explained and after obtaining verbal informed consent, the questions were proposed.

\subsection{Questionnaire}

The information collection was done by interview on the basis of a pre-established questionnaire that we filled ourselves. This questionnaire was validated in a sample of nearly 50 persons.

The questionnaire included questions related to the following information:

1) Presence and characteristics of heartburn as to location and frequency. Heartburn was defined by a discomfort or burning sensation extending from the sternal manubrium to the base of the neck and occurred once a week.

2) Demographic variables: age, gender.

3) Genetic and physiological factor: heartburn in a family member, pregnancy

4) Biometry: body mass index: $\mathrm{BMI}=$ weight, $\mathrm{W}(\mathrm{kg}) /$ height $^{2},(\mathrm{~m})$.

5) Lifestyle and food habitus trigger heartburn: type of food (fat, chocolate), posture, soft drinks or alcohol, tobacco, tea, constipation.

\subsection{Statistical Tests}

A P-value of 0.05 or less was considered to be statistically significant and all reported P-values were two-sided. The data were analyzed using the statistic packaging for social science (SPSS* version 17 California, USA). We used chi-square test for categorical variable, " $t$ " Student for continuous variables and the odds ratio (OR) for the correlations. Univariate and multivariate logistic regression analysis was performed to identify risk factors of heartburn. Our study was consistent with the principles of the Helsinki Declaration of 1975 revised in 1983.

\section{Results}

We interviewed 2025 persons in all sites, excluded 85 persons (inability to correctly answer questions) and ultimately identified 1940 persons (95.8\%). Of these 1940 persons (mean age $28 \pm 9$ years; sex ratio $(\mathrm{M}: \mathrm{F})=0.86$ ), 433 described episode of heartburn. Table 1 shows the characteristics of the study population. Seventy eight women reported being pregnant (7.4\% of the women). The majority of the persons interviewed (60\%) had less than thirty years. Heartburn was described in 22.3\% [95\% CI 21\% - 25\%] cases ( $=433)$. Table 2 shows characteristics of person with heartburn. Heartburn occurred once a week in $9.12 \%$ of case (178 persons). Means of body mass index was respectively in the population study and in person with heartburn 22.9 (standard deviation 
3.2) and 22.8 (standard deviation 3.3). The intensity of heartburn was moderate or mild in $60 \%$ of case. In Table 3 , we present in multivariate analysis potential factors associated with heartburn. Five factors were statistically associated with heartburn: constipation, right lateral decubitus, male sex, after a meal and heartburn in a family member.

\section{Discussion}

Heartburn was described by 433 persons (22.3\%) in our study. The prevalence of heartburn once a week was 9.2\% (178 persons). In most studies, the definition of heartburn was effectively combined with it weekly frequency [3]. On these criteria, the prevalence of heartburn is estimated to $9.2 \%$ in our study, inferior (10\% to 30\%) to that reported in several studies out of Africa [2] [6] [17]-[20]. In Africa, Ntagiribi et al. [16] had observed similar data in student's population where the frequency of heartburn was $22.5 \%$ regardless of the frequency of occurrence. Except of this study, in addition to diagnostic difficulties noted above, the studies in Africa were all performed in a specialized in gastroenterology or endoscopy unit, very unrepresentative of the general population.

\begin{tabular}{|c|c|c|}
\hline Parameter & Effective & Percent \\
\hline \multicolumn{3}{|l|}{ Site } \\
\hline Abidjan east & 251 & $12.9 \%$ \\
\hline Abidjan middle & 419 & $21.6 \%$ \\
\hline Abidjan south & 422 & $21.8 \%$ \\
\hline Abidjan north & 467 & $24.1 \%$ \\
\hline Abidjan west & 381 & $19.6 \%$ \\
\hline \multicolumn{3}{|l|}{ Sex } \\
\hline Male & 898 & $46.3 \%$ \\
\hline Female & 1042 & $53.7 \%$ \\
\hline \multicolumn{3}{|l|}{ Age (years) } \\
\hline [15 - 20] & 261 & $13.4 \%$ \\
\hline$[21-30]$ & 904 & $46.6 \%$ \\
\hline$[31-40]$ & 417 & $21.5 \%$ \\
\hline$[41-50]$ & 221 & $11.4 \%$ \\
\hline [More than 50 years] & 137 & $7.1 \%$ \\
\hline \multicolumn{3}{|l|}{ Digestive symptom* } \\
\hline heartburn & 433 & $22.3 \%$ \\
\hline Regurgitation & 487 & $25.1 \%$ \\
\hline Nausea & 707 & $36.4 \%$ \\
\hline Epigastralgia & 720 & $37.1 \%$ \\
\hline Hiccup & 348 & $17.9 \%$ \\
\hline Eructation & 401 & $20.7 \%$ \\
\hline Dysphagia & 101 & $5.2 \%$ \\
\hline Odynophagia & 50 & $2.6 \%$ \\
\hline \multicolumn{3}{|l|}{ Potentially associated factors } \\
\hline Tobacco & 203 & $10.5 \%$ \\
\hline Alcohol & 645 & $33.2 \%$ \\
\hline Pregnancy women n (\% of women) & 78 & $7.5 \%$ \\
\hline \multicolumn{3}{|l|}{ Body Mass Index $\left(\mathrm{Kg} / \mathrm{m}^{2}\right)$} \\
\hline$<25$ & 1485 & $76.5 \%$ \\
\hline $25-35$ & 403 & $20.8 \%$ \\
\hline$>35$ & 52 & $2.7 \%$ \\
\hline
\end{tabular}

${ }^{*}$ A patient could have more than one symptom. 
Table 2. Characteristics of patients with heartburn.

\begin{tabular}{|c|c|c|}
\hline \multirow{2}{*}{ Parameter } & \multicolumn{2}{|c|}{ Heartburn } \\
\hline & Effective & Percent \\
\hline \multicolumn{3}{|l|}{ Age (years) } \\
\hline [15 - 20] & 67 & $15.5 \%$ \\
\hline$[21-30]$ & 186 & $42.9 \%$ \\
\hline$[31-40]$ & 89 & $20.5 \%$ \\
\hline$[41-50]$ & 55 & $12.7 \%$ \\
\hline [51 and more] & 36 & $8.4 \%$ \\
\hline \multicolumn{3}{|l|}{ Sexe } \\
\hline Male & 180 & $41.6 \%$ \\
\hline Female & 253 & $58.4 \%$ \\
\hline \multicolumn{3}{|l|}{ Intensity } \\
\hline Mild & 95 & $21.9 \%$ \\
\hline Moderate & 165 & $38.1 \%$ \\
\hline Severe & 170 & $39.3 \%$ \\
\hline unspecifing & 3 & $0.7 \%$ \\
\hline \multicolumn{3}{|l|}{ Frequency } \\
\hline Days & 78 & $18 \%$ \\
\hline Week & 100 & $23 \%$ \\
\hline Month & 164 & $38 \%$ \\
\hline Years & 82 & $19 \%$ \\
\hline Unspecifing & 9 & $2 \%$ \\
\hline \multicolumn{3}{|l|}{ Potentially associated factors } \\
\hline Tobacco & 40 & $9.2 \%$ \\
\hline Alcohol & 148 & $34.2 \%$ \\
\hline Percentage of pregnancy women $n$ (\% of women) & 78 & $4 \%$ \\
\hline \multicolumn{3}{|l|}{ Body mass index } \\
\hline$<25$ & 343 & $79.2 \%$ \\
\hline $25-35$ & 77 & $17.8 \%$ \\
\hline$>35$ & 13 & $3 \%$ \\
\hline
\end{tabular}

Table 3. Independent factors of heartburn (multivariate analysis) in the study.

\begin{tabular}{|c|c|c|c|}
\hline Parameter & Odds ratio & $95 \% \mathrm{CI}$ & $\mathbf{P}$ \\
\hline Male sex & 0.555 & $0.331-0.930$ & 0.025 \\
\hline Site of survey & 1.051 & $0.674-1.639$ & 0.826 \\
\hline Tabacco & 0.896 & $0.389-2.064$ & 0.797 \\
\hline Chocolate & 1.241 & $0.752-2.046$ & 0.398 \\
\hline Tea & 0.737 & $0.407-1.334$ & 0.314 \\
\hline Coffee & 0.786 & $0.501-1.234$ & 0.296 \\
\hline Constipation & 2.182 & $1.195-3.983$ & 0.011 \\
\hline Pregnancy & 0.587 & $0.210-1.636$ & 0.308 \\
\hline Hearburn in familily member & 1.765 & $1.143-2.725$ & 0.010 \\
\hline Left lateral decubitus & 0.485 & $0.130-1.818$ & 0.283 \\
\hline Right lateral decubitus & 6.247 & $2.079-18.775$ & 0.001 \\
\hline Supine & 0.823 & $0.465-1.457$ & 0.503 \\
\hline Stress & 1.398 & $0.847-2.308$ & 0.190 \\
\hline Before a meal & 0.905 & $0.514-1.593$ & 0.729 \\
\hline Mornig & 1.179 & $0.750-1.852$ & 0.475 \\
\hline Anteflexion & 1.101 & $0.569-2.129$ & 0.776 \\
\hline After a meal & 2.643 & $1.594-4.383$ & 0.000 \\
\hline Night & 1.331 & $0.846-2.094$ & 0.216 \\
\hline Alcohol & 1.329 & $0.788-2.240$ & 0.286 \\
\hline Soda & 0.783 & $0.483-1.268$ & 0.320 \\
\hline Siesta & 1.206 & $0.783-1.859$ & 0.396 \\
\hline Fat diet & 1.260 & $0.817-1.945$ & 0.296 \\
\hline Body mass index & 0.993 & $0.929-1.062$ & 0.840 \\
\hline
\end{tabular}


Our study recruits individuals only on criteria of geographical location, regardless of whether or not a clinical symptom. Thus, our study focused only heartburn prevalence. Generally in all African studies, patients were recruited either because of gastrointestinal symptoms or in a specialized gastroenterology either from register including gastroscopy and patients with typical symptoms, and atypical extra digestives sign of gastrooesophageal reflux disease. Our work was restricted to the detection of heartburn in persons in one of the five health districts of Abidjan.

Five factors were statistically associated with heartburn in our study: constipation, right lateral decubitus, male sex, after a meal and heartburn in a family member. Constipation during irritable bowel syndrome can be associated with heartburn according to Dent et al. [3]. The literature data were conflicting concerning protective effect of male sex: according to some authors there was a female predominance of Heartburn [1] [2] [21] [22] for others there was no connection with sex [17] [23]. In our study, male sex was less associated with the occurrence of heartburn. But, since heartburn is more frequent during pregnancy, this may have influenced the prevalence in female sex (7.4\% of the women in our study were in pregnancy). There is sparse, but positive, data on the association between gastroesophageal reflux disease and genetic factors in some studies included in the systematic review of Dent et al. [3]. The majority of patients reflux in the right lateral decubitus position. Transient low esophageal sphincter relaxations, primarily in the right lateral decubitus position, are currently recognized as the main pathophysiological abnormality in gastrooesophageal reflux disease [24]. The relationship heartburn and the others factors examined in our study are also not clear as concluded in several studies [1] [3] [24]-[27]. We must forget that other dietary factors (specific to African culture or not) or related to lifestyle (exercise, education, socio-professional category) could influence (or trigger protective effect) heartburn have not been studied in our work. The lack of the gastroscopy is a major limit of the study.

\section{Conclusion}

Heartburn is common in this black African population. Male sex seems less associated with the occurrence of heartburn. Heartburn in a family member is a risk factor. Constipation, right lateral decubitus and after a meal are trigger factors for heartburn.

\section{References}

[1] Moraes-Filho, J.P.P., Chinzon, D., Eisig, J.N., Hashimoto, C.L. and Zaterka, S. (2004) Prevalência da pirose e da doença gastroesofágica numa população urbana brasileira. Arq Gastroenterology, 42, 122-127. http://dx.doi.org/10.1590/S0004-28032005000200011

[2] Bruley Des Varannes, S., Marek, L., Humeau, B., Lecasble, M. and Colin, R. (2006) Gastro Esophageal Reflux Disease in Primary Care. Prevalence, Epidemiology and Quality of Life of Patients. Journal of Clinical Gastroenterology, 30, 364-370. http://dx.doi.org/10.1016/S0399-8320(06)73189-X

[3] Dent, J., El-Serag, H.B., Wallander, M.A. and Johansson, S. (2005) Epidemiology of Gastrooesophageal Reflux Disease: A Systematic Review. Gut, 54, 710-717. http://dx.doi.org/10.1136/gut.2004.051821

[4] Nocon, M., Labenz, J. and Willich, S.N. (2006) Lifestyle Factors and Symptoms of Gastro-Esophageal Reflux-A Population-Based Study. Alimentary Pharmacology \& Therapeutics, 23, 169-174. http://dx.doi.org/10.1111/j.1365-2036.2006.02727.x

[5] Ronkainen, J., Aro, P., Storskrubb, T., Johansson, S.E., Lind, T. and Bolling-Sternevald, E. (2005) High Prevalence of Gastro Esophageal Reflux Symptoms and Esophagitis with or without Symptoms in the General Adult Swedish Population: A Kalixanda Study Report. Scandinavian Journal of Gastroenterology, 40, 275-285. http://dx.doi.org/10.1080/00365520510011579

[6] Wiklund, I., Carlsson, J. and Vakil, N. (2006) Gastro Esophageal Reflux Symptoms and Well-Being in a Random Sample of the General Population of a Swedish Community. American Journal of Gastroenterology, 101, 18-28. http://dx.doi.org/10.1111/j.1572-0241.2005.00343.x

[7] Djibril, M.A., M’Ba, K.B. Kaaga, Y.L., Bagny, A., Edou, K.A. and Redah, D. (2009) Endoscopie digestive haute en milieu rural africain au Togo. Medical Tropics, 69, 48-50.

[8] Ilboudo, P.D., Sawadogo, A., Serme, A.K., Bougouma, A. And Toguyeni, L.A. (2005) Pathologie du reflux gastrooesophagien chez l'adulte noir africain. Médecine d'Afrique Noire, 52, 51-55.

[9] Klotz, F. and Debonne, J.M. (1991) Y a-t-il une pathologie du reflux gastro-oesophagien en Afrique noire? Médecine D'afrique Noire, 38, 41-47.

[10] Diouf, M.L., Dia, D., Mbengue, M., Pouye, A., Diallo, S. and Moreira-Diop, T. (2002) Gastro-Esophageal Reflux in 
Adults: Clinical and Endoscopic Features at the Le Dantec Hospital of Dakar. Dakar Medicine, 47, 142-146.

[11] Onyekwere, C.A., Hameed, H., Anomneze, E.E. and Chibututu, C. (2008) Upper Gastrointestinal Endoscopy Findings in Nigerians: A Review of 170 Cases in Lagos. Nigerian Postgraduate Medical Journal, 15, 126-129.

[12] Tall, A. and Diop, E.M. (2008) The Otolaryngological Manifestations of Gastroesophageal Reflux Disease. Dakar Medicine, 53, 142-149.

[13] Harouna, Y.D., Illo, A., Assoumane, I., Onuoha, C., Abdou, I., Goza, A., Diakite, I., Madougou, B. and Seydou, A. (2008) Les cancers de l’oesophage au Niger à propos de 36 cas. Médecine d'Afrique noire, 55, 235-239.

[14] Segal, I. (2001) The Gastro-Oesophageal Reflux Disease Complex in Sub-Saharan Africa. European Journal of Cancer Prevention, 10, 209-212. http://dx.doi.org/10.1097/00008469-200106000-00003

[15] Ntagirabiri, R., Mumana, A., Baransaka, E., Niyonzima, S. and Ndayishimiye, H. (2013) Reflux gastro-œsophagien dans la population consultant à Bujumbura. Journal Africain d'Hépato-Gastroentérologie, 7, 204-207. http://dx.doi.org/10.1007/s12157-013-0496-6

[16] Ntagirabiri, R., Niyonzima, S., Mumana, A.-L. and Ndabaneze, E. (2013) Reflux gastro-œsophagien chez l'adulte jeune africain: Cas des étudiants de l’Université du Burundi. Journal Africain d'Hépato-Gastroentérologie, 7, 192-195. http://dx.doi.org/10.1007/s12157-013-0489-5

[17] Bollschweiler, E., Knoppe, K., Wolfgarten, E. and Hölscher, A.H. (2007) Prevalence of Reflux Symptoms in the General Population of Cologne. Z Gastroenterol, 45, 177-181. http://dx.doi.org/10.1055/s-2006-927402

[18] Sharma, P.W., Romero, S.Y. and Hamilton, D.F. (2008) Racial and Geographic Issues in Gastroesophageal Reflux Disease. American Journal of Gastroenterology, 103, 2669-2680. http://dx.doi.org/10.1111/j.1572-0241.2008.02089.x

[19] Salis, G. (2011) Systematic Review: Epidemiology of Gastroesophageal Reflux Disease. Latin America Acta Gastroenterol Latinoam, 41, 60-69.

[20] Chiocca, J.C., Olmos, J.A., Salis, G.B., Soifer, L.O., Higa, R., Marcolongo, M. for the Argentine. An Gastro-Oesophageal Reflux Study Group (2005) Prevalence, Clinical Spectrum and Atypical Symptoms of Gastro-Oesophageal Reflux in Argentina. A Nationwide Population-Based Study Aliment Pharmacological Therapy, 22, 331-342. http://dx.doi.org/10.1111/j.1365-2036.2005.02565.x

[21] Dore, M.P., Maragkoudakis, E., Fraley, K., Pedroni, A., Tadeu, V. and Realdi, G. (2008) Diet, Lifestyle and Gender in Gastro-Esophageal Reflux Disease. Digestive Diseases and Sciences, 53, 2027-2032. http://dx.doi.org/10.1007/s10620-007-0108-7

[22] Chen, Z., Thompson, S.K., Jamieson, G.G., Devitt, P.G. and Watson, D.I. (2011) Effect of Sex on Symptoms Associated with Gastroesophageal Reflux. Archives of Surgery, 146, 1164-1169. http://dx.doi.org/10.1001/archsurg.2011.248

[23] Vakil, N., van Zanten, S.V., Kahrilas, P., Dent, J. and Jones, R. (2006) Global Consensus Group. The Montreal Definition and Classification of Gastroesophageal Reflux Disease: A Global Evidence-Based Consensus. American Journal of Gastroenterology, 101, 1900-1920. http://dx.doi.org/10.1111/j.1572-0241.2006.00630.x

[24] Ouatu-Lascar, R., Lin, O.S. Fitzgerald, R.C. and Triadafilopoulos, G. (2001) Upright versus Supine Reflux in Gastroesophageal Reflux Disease. Journal of Gastroenterological Hepatology, 16, 1184-1190. http://dx.doi.org/10.1046/j.1440-1746.2001.02581.x

[25] El-Serag, H.B., Hill, C. and Jones, R. (2009) Systematic Review: The Epidemiology of Gastro-Oesophageal Reflux Disease in Primary Care, Using the UK General Practice Research Database. Alimentary Pharmacology \& Therapeutics, 29, 470-480. http://dx.doi.org/10.1111/j.1365-2036.2008.03901.x

[26] Kahrilas, P.J. (2008) Gastroesophageal Reflux Disease. New England Journal of Medicine, 359, 1700-1707. http://dx.doi.org/10.1056/NEJMcp0804684

[27] El-Serag, H.B., Satia, J.A. and Rabeneck, L. (2005) Reflux Disease: A Cross Sectional Study in Volunteers Dietary Intake and the Risk of Gastro-Oesophageal. Gut, 54, 11-17. http://dx.doi.org/10.1136/gut.2004.040337 